\title{
OBRAZ BISKUPA V ROMÁNSKEJ DOBE (POL. 11. - POL. 13. STOROČIA)
}

\author{
The Image of a Bishop in Romanesque Times \\ (mid-11th - mid-13th Century)
}

\author{
Peter Zubko
}

DOI: $10.17846 / C L .2020 .13 .2 .52-64$

\begin{abstract}
ZUBKO, Peter. The Image of a Bishop in Romanesque Times (mid-11th - mid-13th Century). In the 11th century, several reforms took place in the Catholic Church, which also concerned the ministry and position of bishops. Bishops formed only a small but influential part of the life of the Christian community. From the Romanesque period, the first detailed information about the life of bishops from non-hagiographic sources has been preserved. At the same time, requirements were defined as to the characteristics of an orthodox Catholic bishop. During this period, the office of archbishop was established. The bishop was elected by the chapter according to the usual rules. The importance of the cathedral and the episcopal liturgy increased. The bishops reserved some sacramental acts and decisions just for themselves. The four Lateran Councils paid wide attention to the bishops; the article lists all the relevant canons of these councils on bishops. In Romanesque times, the position of the bishop in the Catholic Church was highlighted and strengthened, and at the same time he gained an important place in secular society. The bishops were autonomous vis-à-vis the pope, so the individual dioceses differed from each other, but certain intellectual, cultural and spiritual influences had an impact on the universal Christian community. The bishops had an important say in the administration of the lands, they were advisers to the rulers, and only those who met certain qualities (which was new compared to the previous time) could be bishops, but on the other hand it was not possible to bypass the rulers with the appointment. This heritage was influential until the late middle ages.
\end{abstract}

Keywords: Middle Ages (Romanesque period), bishop, Lateran Councils, Episcopal Reserves, cathedral

Jedenáste storočie v dejinách katolíckej cirkvi bolo časom reforiem v protiklade s predchádzajúcim obdobím, ktoré historici nazvali temným storočím (lat. saeculum obscurum). Obrodu začal pápež Gregor VII. (1073 - 1085) s predpripravenou pôdou už pápežom Levom IX. (1049 - 1054). Obroda reholného života zas vychádzala z opátstva v Cluny. Išlo predovšetkým o vnútornú obnovu cirkevného a duchovného života, ale vo vztahoch medzi cirkevnou (duchovnou) a svetskou (sekulárnou) spoločnostou, čiže o vzţahy medzi cirkvou a štátom. Dvanáste storočie prinieslo kultúrne zmeny: Európu prestali sužovat vpády cudzích, pohanských vojsk, nastal ekonomický rast, boli založené prvé univerzity (Bologna 1158), európska kultúra vstúpila do svojho klasického veku (porov. Leonardi 2014). Viacerí teológovia a kánonisti výrazne prispeli k rozvoju teológie, filozofie (scholastika) a kánonického práva. Krest’ania viedli osem krížových výprav (1096 - 1270). Na prelome 12. a 13. storočia sa objavujú nové, mendikatské rehole (McGrath 2014, 148-194; 
Ráček 1940, 200-252). Celá stredoveká spoločnost’ prechádza istou sakralizáciou, vrátane príbehov, symbolov a rozprávaní (porov. Pastoureau 2011).

Honorius Augustodunensis namiesto tripartitnej spoločnosti prirovnal spoločnost’ ku kostolnej budove, kde stĺpmi boli biskupi, vitrážami majstri, klenbami kniežatá, strešnou krytinou rytieri, dlažbou lud. Saský františkán Konrád v 13. storočí prirovnával oltár s Kristom, veže s pápežom a biskupmi, chór s klérom a lod's laikmi. Bertold $\mathrm{z}$ Rezna rozlišoval desat' spoločenských tried, ktoré zodpovedali desiatim anjelským zborom. Istý nemecký kazatel’ z roku 1220 vyrátal až 28 stavov: 1. pápež, 2. kardináli, 3. patriarchovia, 4. biskupi, 5. preláti, 6. mnísi, 7. križiaci, 8. laici, 9. potulní mnísi, 10. svetskí kňazi, 11. juristi a lekári, 12. študenti, 13. potulní študenti (vaganti), 14. reholníčky, 15. cisár, 16. králi, 17. kniežatá a grófi, 18. rytieri, 19. šlachtici, 20. panoši, 21. meštania, 22. obchodníci, 23. kupci, 24. heroldi, 25. poslušný vidiecky lud, 26. vzdorovitý vidiecky lud, 27. ženy, 28. bratia kazatelia. V skutočnosti pápež viedol klérus a cisár laikov (Le Goff 2005a, 348; porov. Le Goff 1999). V tomto stredovekom svete tvorili biskupi len malú čast', ale významnú a vplyvnú. ${ }^{1}$

\section{Obrodenie svetského kléru}

Od 11. storočia sa zachovali rôznorodejšie pramene, vdaka čomu je možné venovat podrobnejšiu pozornost’ svetskému kléru, jeho štruktúram, každodennosti, pastoračnej práci, vzájomným vztahom. Dovtedy v literatúre medzi žánrami prevládali Gesta a Vitae, ktoré majú hagiografickú povahu, lebo hovoria o kanonizovaných svätcoch a treba v nich vediet' kriticky čítat. Teraz pribúdajú pramene svetskej povahy či úradnej (korešpondencia, spisy kapitúl, kláštorov), ale i súkromnej. Popritom vznikajú teologické, homiletické traktáty, liturgické knihy. To všetko je jedinečným prameňom informácií. Samozrejme, že medzi jednotlivými krestanskými krajinami v Európe existovali regionálne špecifiká a za prevládajúcimi prúdmi bolo cítit’ oneskorovanie (porov. Hledíková 2002, 139-165).

Velký znalec kánonického práva Gracián teoreticky opísal a vysvetlil trojaké biskupské poslanie: kňazské, učitel'ské a pastoračné. Tieto funkcie z biskupov robia hierarchov, ktorí stoja medzi farármi a pápežom. Tu vzniká pohlad na biskupstvo ako na miestnu cirkev, kedysi pri vzniku cirkevnej organizácie chápanú ako farnost'. Tak sú biskupom rezervované niektoré úkony sakrálnej povahy: birmovanie, ordinácia a čiastočne spoved' (rozhrešovanie rezervátov). Rituály sa rozmnožili nielen v prípade orda svetských osôb (biskup udeloval nižšie a vyššie svätenia), ale zasahoval aj do života reholí a kláštorov (benedikcie opátov a opátok, prijímanie slubov mníšok), bežných farností (posviacky kostolov, cintorínov) a života spoločnosti (prenášanie relikvií - kanonizácia).

V karolínskych kapitulároch sa často biskup charakterizuje ako muž s čnostami čistoty, lásky k blížnemu a pokory - ide o vlastnosti, ktoré boli v predošlom 10. - 11. storočí opomínané; je kritizovaná simonia, porušovanie celibátu. Vznikol tak nový prototyp biskupa: ten, čo stojí bližšie k veriacim, ktorý je povinný dvakrát ročne zvolat diecéznu synodu, na ktorej oznámi rozhodnutia pápeža, exkomunikuje hriešnikov, dá pastoračné a disciplinárne usmernenia, urovná miestne spory, vyrieši problémy. Vtedy sa stretne aj s predstavenými kláštorov a kapitúl. Závery synod sú zverejňované na spôsob synodálnych štatútov a kánonov, ktoré mali častejšie pastoračnú povahu a viac zasahovali do života $\mathrm{v}$ bežných farnostiach. Biskupi dohliadajú na mníšske i kanonické rehole; najmä v 12. storočí výrazne stúpa počet kláštorov i kapitúl. To znamená aj zvýšenie počtu

Tejto problematike sa v literatúre venuje menšia pozornost'. Nasledujúca čast’ je zostavená na základe dostupnej literatúry (Parisse 2001, 209-236; Walton - Hannah - Lynn Peterson 2008; Kryštůfek 1889, 255258; Carrol 2009). 
konfliktov, do ktorých biskup vstupuje ako sudca: ide o spory majetkové, kompetenčné, pastoračné, a to nielen medzi konventmi navzájom, ale i konventmi a farnostami. Benediktíni a niektoré kánonické rehole sa snažili vymanit’ sa spod moci biskupov tzv. exempciou, hoci od 12. storočia sa paradoxne o biskupskú priazeň ešte viac usilovali, aby si tak zabezpečili vplyv. Bohatí a vplyvní opáti, ktorí mali majetky v niekol'kých diecézach sa tak častokrát stávali mimoriadne cennými poradcami biskupov, ale i konkurentmi. Rozsiahly kláštorný majetok tvoril čast̉ biskupského vlastníctva.

\section{Diecézy a episkopáty}

V dejinách krestanskej Európy biskup nebol len duchovným pastierom, ale tiež svetským pánom, ktorý slobodne spravoval svoje územie, bol rovný kniežatám, v prípade vojny postavil vlastných vojakov alebo razil vlastné mince. Neraz biskup vlastnil nejaké pevnosti alebo hrady, lesy, usadlosti, mýta i opátstva v iných diecézach, teda na území v jurisdikcii iného biskupa. Čím väčší a rozsiahlejší majetok, tým väčšia moc katedrálneho chrámu a jeho svätého patróna. Tak mohol biskup ako autorita intervenovat proti komukolvek, kto upieral práva biskupovým podriadeným (farárom) v jeho diecéze (cirkevná geografia), ale tiež na jeho majetkoch mimo vlastnej diecézy (teritoriálna geografia). Je zrejmé, že svetské autority venovali výberu biskupa mimoriadnu pozornost'. Vo velkostiach biskupstiev existoval vel'ký nepomer. V Anglicku, Francúzsku boli diecézy relatívne rozsiahle, $\mathrm{v}$ južnej Itálii maličké a biskup sídlil v každom významnejšom meste. V Anglicku sa biskupi presídlovali od katedrál do väčších a významnejších miest, v Ríši sa hranice nemenili, hoci územné rozdelenie bolo komplikované, no stabilné vd’aka hustej sieti opevnených biskupských hradov a vynikajúco stráženým hraniciam so svetskými panstvami. Kolín, Mohuč, Liège, Metz a mnohé dalšie nemecké diecézy si po stáročia zachovali charakter svetských kniežatstiev. Ak si porovnáme talianskeho biskupa, spravujúceho len niekol'ko desiatok farností, a nemeckého biskupa, ktorý spravoval niekolko stoviek farností, je zjavný nielen ekonomický, ale aj pastoračný nepomer: vo väčšej diecéze sa pozornost̉ sústredovala viac na hmotné dobrá, kým v menšej na pastoráciu.

\section{Spoločné problémy hierarchie}

Na pomyselnom rebríku cirkevnej hierarchie medzi biskupmi a pápežom stál arcibiskup (ako predstavený cirkevnej provincie) a časom prímas. Hranice medzi cirkevnými provinciami prebiehali zhodne s tradíciou podla provincií rímskeho cisárstva. Toto rozdelenie nebolo geograficky ideálne, $\mathrm{v}$ tej istej krajine boli povedla seba ideálne i neideálne riešené provincie, niektoré boli vel’mi malé (Embrun a Aix v Provans), iné rozsiahle (Mohučská cirkevná provincia so 14 sufragánnymi biskupstvami siahala od Rýnu do Prahy). Arcibiskup získaval jurisdikciu prijatím pália od pápeža. Ambície cirkevných a svetských kniežat plodili konflikty, ktoré trvali i niekolko desat'ročí. Nové štáty stredovýchodnej Európy tiež ustanovovali vlastné cirkevné provincie.

Arcibiskup bol vyberaný priamo na tento post, len výnimočne bol predtým niekde biskupom. Funkcia arcibiskupa nebola jasne definovaná, preto dôležitú úlohu tu zohrávala osobnosț takého človeka. Niektoré úlohy boli rezervované len arcibiskupovi, napríklad dohliadanie na sufragánnych biskupov v cirkevnej provincii, ktorých konsekroval v katedrálach spolu s inými dvoma biskupmi z tej istej provincie; rovnako mal právo vizitovat’ všetky biskupstvá svojej provincie; vznikol zvyk pri sporoch obrátit sa na arcibiskupa ako na poslednú odvolaciu inštanciu. Sufragánni biskupi mali podiel na jeho rozhodnutiach prostredníctvom hlasovacieho práva $\mathrm{v}$ úlohe jeho poradcov. 
Arcibiskup mal povinnost’ pravidelne zvolávat riadne provinčné synody. Tieto práva sa však v románskej dobe len vyvíjali a jasnejšie ich vieme opísat až v 12. storočí. Synody často zvolávali svetskí vládcovia alebo pápežskí legáti, aby riešili spory o investitúru, alebo aby sa zaoberali reformátorskými snahami, len okrajovo sa zaoberali konkrétnou správou cirkevných provincií.

Existoval jeden nadprovinčný problém, ktorý sa týkal hodnosti prímasa. Jeho podstata spočívala v špecifickej pozícii, vyvýšenej nad ostatných biskupov, bol osobitým predstavitelom Svätej stolice $\mathrm{v}$ krajine a jeho pozícia sa rovnala postaveniu panovníka. Aj tu existovali rozdiely: primát Lyonu vo Francúzsku bol ovela menej významný ako primát Canterbury v Anglicku. Niektorí biskupi a arcibiskupi získali vysoké hodnosti a dôležité funkcie, takže stáli vysoko nad inými; navyše biskupi a arcibiskupi, v službách panovníkov ako kancelári, mali osobitne vel'kú moc; tí, ktorých pápež vymenoval za svojich legátov, časom spravovali súdy. V 12. storočí činnost' legátov bola všeobecne značná a niekde aj nahrádzala vládu biskupov.

Kánonické právo ustálilo právomoc metropolitov v rámci cirkevných provincií. Do ich kompetencií patrilo: 1. schválenie volby sufragánnych biskupov a ich konsekrácia, 2. zvolávanie a predsedanie provinčných synod, 3. dohlad a kánonická vizitácia sufragánnych biskupstiev, trestanie sufragánov cirkevnými cenzúrami, 4. odvolacia druhá inštancia na riešenie sporov zo sufragánnych biskupstiev, 5. devolučné právo (suplovanie zanedbaných povinností sufragánov). V správe diecéz nastali výrazné zmeny. Vyvinul sa stupeň arcidiakonov (v Uhorsku sa ich právomoc zvyčajne kryla s územím stolice alebo jej časti), pretože biskupi sa bud' nevenovali dostatočne svojej službe a uprednostňovali svetskú či panovníkovu spoločnost', alebo išlo o rozsiahle biskupstvá. Ich právomoc zodpovedala jurisdikcii vikárov na území svojho arcidiakonátu a bola delegovaná od biskupa. Od 12. storočia sa biskupi snažili obmedzovat právomoci arcidiakonov zavedením funkcie generálnych vikárov, ktorí prevzali dovtedajšiu agendu arcidiakonov. Tridentský koncil akúkolvek právomoc arcidiakonov zrušil, v Uhorsku však táto hodnost̉ prežila ako viac-menej honorárna funkcia. Od 13. storočia sa viacerí zaneprázdnení biskupi nechali zastupovat svätiacimi alebo titulárnymi biskupmi pri pontifikálnych liturgických slávnostiach. Svätiaci biskup bol $\mathrm{v}$ podstate rituálny pomocník s biskupskou vysviackou. Jeho menovanie sa viazalo na priradenie niektorej zaniknutej diecézy vo vtedajšom mohamedánskom svete. V Uhorsku po obsadení južných častí krajiny Osmanmi (episcopi in partibus infidelium) boli napríklad viacerí spišskí prepošti súčasne titulárnymi biskupmi už neexistujúcich uhorských biskupstiev, hoci nemali biskupskú konsekráciu (tzv. episcopi electi) (Špirko 1943 [1945], 429-430).

\section{Osobnost' biskupov}

O osobnostiach biskupov a arcibiskupov 11. a 12. storočia vieme ovela viac ako o ich predchodcoch. Všeobecne možno povedat, že biskup 12. storočia mal aristokratický pôvod a dobré vzdelanie. Kedže hodnost biskupa sa spájala s výkonom moci, úrad biskupa bol predurčený limitovanej spoločenskej a intelektuálnej elite pochádzajúcej z vysokej šlachty. Po zmenách v spôsobe výberu biskupa katedrálnymi kapitulami sa výrazne zvýšil podiel ludí pochádzajúcich zo šlachty v danej diecéze alebo cirkevnej provincii. Len niektoré miesta s výnimočnejším postavením prihliadali pri výbere na potenciál učencov z celej krajiny (Paríž). V Ríši staršia prax výberu miestnych kandidátov tiež upadla. Do kapitúl sa dostáva nižšia šlachta, ale ešte nemala prístup k biskupskej hodnosti, s výnimkou Itálie, kde je vela biskupstiev a málo vysokej šlachty. V niektorých krajinách sa biskupmi stávali aj ludia neurodzeného pôvodu, nevolníci (nemecké krajiny) či rytieri.

V 12. storočí je biskup vyberaný spomedzi kanonikov katedrálnej kapituly, ale napríklad v južnom Francúzsku sa biskupmi stávajú aj mnísi, najmä benediktínski opáti alebo premonštráti, už pomenej cisterciti. Zaujímavý prípad je Anglicko, kde polovicu katedrálnych kapitúl tvorili 
reholníci. Všade tam, kde sa katedrálny klérus cítil silný, vystačil si s výberom skvelých kandidátov na biskupov, pričom vyberal takých, ktorí už úspešne vykonávali nejakú funkciu: farára, arcidiakona, kantora alebo vedúceho katedrálnej školy.

Biskup bol najčastejšie vzdelaný muž, plne oddaný svojej službe. Ked’ kláštorné školy zažívali stagnáciu alebo úpadok, katedrálne školy zintenzívňovali výuku. Viaceré takéto učilištia sa zanedlho stali univerzitami. Biskupi získali vzdelanie neraz v cudzine alebo mimo svojej diecézy. Povest̉ známeho učenca mohla mat’ vážny vplyv na výber biskupa. Sú známe prípady biskupov nevýznamného pôvodu, ktorí svojím nadaním, trpezlivostou, usilovnostou a intelektuálnou i praktickou schopnostou boli vybraní za biskupov vo významných diecézach, a to i daleko od ich rodiska, najmä ak v takých rodných končinách chýbali školy.

Ďalšou kategóriou boli biskupi, ktorí pred svojím zvolením boli duchovnými alebo radcami na kniežacích dvoroch (porov. Dvořáčková-Malá - Zelenka a kol. 2014, 387-389). Výber královských priaznivcov sa vysvetluje tým, že boli vhodní pre toto poslanie, alebo že panovníkovi záležalo na obsadení klúčových miest lud’mi z jeho blízkosti. Prirodzene, tu vznikli nové problémy vo vztahu medzi cirkvou a štátom a tiež v spôsobe výberu biskupov po reforme. Vzájomný vztah krála a cirkvi symbolizuje obrad korunovácie, ktorú mohol vykonat len biskup. Královské pomazanie dovolovalo pomazanému panovníkovi dokonca posluhovat pri omši v úlohe subdiakona. Na druhej strane král' ochraňoval cirkev, bol jej hlavný ochranca (porov. Roux 2009, 249-250; Kantorowicz 2014). Odvolávajúc sa na údajnú prax tohto obdobia, vznikla v ranonovovekom Uhorsku idea o tzv. hlavnopatronátnom práve, podla ktorého mal uhorský král napr. právo zriadovat' nové biskupstvá.

\section{Volba biskupa}

Postup pri volbe biskupa bol teoreticky jasne ustálený. Ked’ sa biskupský stolec uprázdnil, zišla sa katedrálna kapitula, aby zvolila nového biskupa. Pravdepodobne z predchádzajúcich rokovaní vznikla propozícia, ktorú kanonici potvrdzovali hlasovaním. Definitívne potvrdenie prináležalo arcibiskupovi alebo panovníkovi. Ustálil sa čas biskupskej konsekrácie - nedela. Ak sa konala aj svetská investitúra, bola udelovaná takisto vtedy. Každá fáza volby bola chodením po tenkom lade a jej výsledok nebol vždy istý. Ťažko hovorit o slobode voličov, vplyve arcibiskupov, svetských kniežat alebo panovníkov či pápeža, vždy však muselo dôjst’ k väčšinovej zhode.

Čoraz častejšie sa vyskytovali prípady zvolených biskupov, ktorí neboli hned’ svätení (tzv. electi), a v 12. storočí boli takí rozšírení, že sa otvorila otázka, či nekonsekrovaný biskup má právo spravovat svoju diecézu. Ustálilo sa pravidlo, že electus nemá právo spravovat biskupstvo, kým svetské knieža nepotvrdí jeho volbu, preto absencia investitúry mohla nebezpečne predlžovat’ obdobie vakancie. Zvolený mohol váhat o prijatí konsekrácie z rúk arcibiskupa, ak s ním nemal dobré vztahy, najmä ak sa rozchádzali v politických názoroch. Tretí lateránsky koncil ustanovil, že electus nemôže vysluhovat' kňazské svätenia. Súčastou investitúry bolo odovzdávanie regálií, čím biskup získal napríklad právo výberu poplatkov. V Ríši a vo Francúzsku sa z oddalovania investitúry stal vážny kánonický problém vztahovov medzi cirkvou a štátom. Problém investitúry vyriešil až Wormský konkordát (1122).

Obdobie trvania sedesvakancie biskupského stolca nemal trvat dlhšie než tri mesiace. Vo Francúzsku král kontroloval menej než polovicu biskupstiev. Král’ v čase vakancie tažil z postavenia suveréna a poberal biskupské príjmy z neobsadených miest. Ked' král podporoval vlastných kandidátov, mohlo to tiež vyvolat odpor vo vnútri cirkvi. Bernard z Clairvaux celý život rázne vystupoval proti takým kandidátom, královmu vplyvu a vnucoval kandidátov podla svojho uváženia. Ešte vypuklejším sa stal prípad Tomáša Becketa v Anglicku. Henrich II. Plantagenet 
vymenoval svojho kancelára za arcibiskupa v Canterbury. Tento syn kupca z Rouen mal najlepšie vzdelanie a priatelil sa s Jánom zo Salisbury. Svojou uvážlivou politikou vrátil královi autoritu, panovník ho 21. mája 1162 vymenoval za prímasa. Následne došlo k zmene: ako vehementne Tomáš dovtedy vystupoval ako králov kancelár, tak teraz sa stal obrancom práv anglickej cirkvi, pretože považoval duchovnú moc za nadradenú svetskej moci. Tomáš odmietol potvrdit obyčajové právo potvrdením verzie artikúl zostavených králom. Spor s králom skončil vraždou Tomáša v katedrále 29. decembra 1170. Henrich II. bol zavrhnutý zo všetkých strán, až napokon rezignoval na královský trón. Konkordát v Avranches (1172) obsahuje vela kompromisov zo strany panovníka presne v duchu mučeníka z Canterbury.

\section{Biskupský kostol}

Suger, duchovný syn sv. Benedikta, postavil kláštorný kostol s výrazne mestským charakterom. Dal tak príklad, aby v jeho diele pokračovali biskupi a farári velkých a významných miest. Vo Francúzsku 12. storočia tak boli postavené (alebo do tejto podoby prestavané) architektonické prototypy katedrálnych chrámov, ktoré ovplyvnili celé stredoveké obdobie. Katedrály ako biskupské chrámy sa stali symbolom moci cirkvi. Biskupi boli súčastou stredovekej hierarchie a boli považovaní za piliere královskej moci. Pri biskupovi existovala kapitula. Biskup i kanonici ekonomicky tažili z viacerých zdrojov stredovekého hospodárstva. Na jednej strane mali inštitúcie dôležité a významné pre krajinu rozsiahle fundačné majetky, rozsiahle nehnutelnosti, potom participovali na miestnom obchode (oficiálnom i neoficiálnom), poberali desiatky, dostávali milodary. Kupcom sa opakovane prízvukovalo, že sa svojou prácou nemôžu zapáčit Bohu, lebo sa obohacujú na úkor bratov, preto si chceli zlé svedomie vykúpit štedrostou voči cirkvi. Vo Francúzsku bol v 12. storočí zisk stále považovaný za smrtelný hriech. Cirkev na to do istej miery zareagovala náukou o očistci (porov. Le Goff 2003). V románskej dobe dary od majetných veriacich (krála, šlachty, meštanov, obchodníkov) tvorila väčšinou hotovost’, nie nehnutelnosti. Biskup mohol pri každej významnej cirkevnej stavbe rátat s královou pomocou. Král býval najštedrejším mecenášom a biskupi boli blízkymi príbuznými krála alebo jeho familiármi. Biskup bol priatel panovníka. Iniciatívy biskupa mali v prvom rade upevnit jeho moc a slávu. Stávalo sa $\mathrm{z}$ neho skutočné duchovné knieža s vel'kou autoritou. Najväčším hrdinstvom biskupa bolo postavenie novej katedrály. Jednotliví biskupi sa medzi sebou predbiehali, kto postaví krajší chrám, hoci by išlo len o prestavbu predsiene. Slávu si biskupi zabezpečovali vytesaním svojich podobizní v kamenných prvkoch alebo na vitrážach, alebo mal'bách. Neskôr tento spôsob vtierania sa do priazne panovníkom a biskupom využili i mestá, ked’ svojich ochrancov malovali alebo iným spôsobom pripomínali vo svojich mestských kostoloch. Katedrály neboli len centrom biskupskej liturgie, ktorá bola - prirodzene - prvotriedna (čo do kvality i početnosti účinkujúceho kléru, kvality liturgického spevu, druhu obradov), ale aj spoločenského života a kultúrneho diania v danej lokalite. Toto prepojenie sa znásobilo prepájaním medzi civilnou a sakrálnou sférou tak, že obchodníci (neskôr tovarišstvá, cechy) financovali zhotovenie vitráží a neskôr oltárov a svojich oltárnikov. Cirkev zas cez tieto osoby a združenia osôb dokázala ovplyvňovat krestanskú morálku v ich okolí. Najlepšie vzdelanie po stáročia sprostredkúvali kláštorné školy. Vo Francúzsku v 11. storočí svetský klérus prepadol rytierskej hrubosti a kláštory sa uzavreli do seba. Monopol na vzdelávanie tak prešiel na biskupov. Mnísi v klauzúre sa modlili odrezaní od sveta. Biskupovo postavenie však bolo také významné, že sám sa o školu nestaral, túto funkciu zveroval klerikom, kanonikom. V biskupskej škole dostalo vyučovanie nový štýl, bolo otvorené skutočnému životu. Kým v kláštoroch prebiehalo vzdelávanie na individuálnom prístupe, nanajvýš sa vzdelávala dvojica novicov, katedrálne školy vzdelávajú skupiny študentov. Učitel študentom predčítal knihu a komentoval ju. Študenti sa združovali 
do spolkov, nežili izolovane, ale chodili do spoločnosti, túlali sa, takmer všetci boli klerikmi, nosili tonzúru, na krátko ostrihané vlasy a typické oblečenie, čiže boli lahko identifikovatelní a spadali do biskupovej jurisdikcie. Ak sa rozhodli zanechat svetský život a nestali sa rytiermi, čakala ich slubná cirkevná kariéra. Štúdium malo sakrálny rozmer. Absolventi už ako klerici medzi laikmi šírili poznanie Boha a upevňovali pozície cirkvi (porov. Duby 2002, 113-122).

\section{Ortodoxia}

Biskupi boli strážcami pravovernosti vo svojej diecéze. Neexistovala rímska centralizácia v záležitostiach viery a mravov, ako ju poznáme z novoveku. Ak sa vyskytlo nejaké mravné alebo dogmatické pochybenie, biskup okamžite zasiahol (porov. Lambert 2000; Patschovsky 2018). Štvrtý lateránsky koncil k tomu výrazne napomohol ustanoveniami o biskupskej inkvizícii. Niektoré záležitosti si síce rezervoval pápež, napríklad právo vyhlásit niekoho za svätého, v románskej dobe v niektorých regiónoch toto právo biskupi ešte využili. Ak sa niekde udiali tzv. zázračné udalosti, biskup ich preskúmal a bud' potvrdil, alebo zakázal. Biskupi neboli vysunutými nástrojmi pápeža, ale konali autonómne (Jedin 1990, 38), no najmä sa stali nezávislými na svetskej moci (Chélini 1996, 233). Svetskí historici toto isté obdobie hodnotia ako dominanciu pápežstva (porov. Fried Hehl 2013, 214-218), no v podstate ide o obrodenú katolícku cirkev na čele s pápežom (Roberts 2002, 253-267). Životaschopnost’ a dynamiku tohto prostredia zabezpečila sloboda individualít biskupov, ktorí mohli konat primerane potrebám svojich diecéz, univerzálnym požiadavkám a vlastným ambíciám.

Pred vznikom mendikantských reholí boli častým fenoménom potulní kazatelia. Ich poslucháčmi boli mestské elity, bývalí rytieri, právnici, obchodníci, ktorých biskupský rítus neuspokojoval, pretože hladali spásu. Často sa im ale pripomínalo, že charakter ich práce a skutkov ich - podla zaužívaných stereotypných názorov - zo spásy vylučoval. V katedrále sa totiž zvyčajne spievalo, nie kázalo. Potulní kazatelia sa prihovárali na križovatkách ciest, hovorili priamo do konkrétnej duchovnej situácie poslucháča a kázali v jeho jazyku. Zvyčajne to boli odpadnutí klerici, ktorí si nevedeli predstavit svoj život medzi kanonikmi z bohatých vrstiev. Potulní kazatelia mali zvyčajne nižší sociálny pôvod a neuspokojoval ich ani kláštorný, ani pustovnícky život. Potencionálne boli zdrojom nespokojnosti, a preto ich biskupi prenasledovali. Väčšina kazatelov hlásala pokánie, vyzývala na reformu cirkvi. Ako pomôcku na tvorbu kázní používali exemplá (Le Goff 2005b, 91-94). Tak vznikli niektoré kacírske hnutia. Kacíri označovali katedrálny klérus za skazený a nemravný a za príčinu tohto úpadku bolo označené bohatstvo: Akú hodnotu majú sviatosti, ktoré potom vysluhujú? Ak chce byt lud spasený, musí takýchto nemravníkov pozbavit ich moci. Tieto názory narúšali stabilitu spoločnosti a priviedli kacírov na hranicu alebo do väzenia. Mystika chudoby bola považovaná za nebezpečnú, preto cirkev váhala s potvrdením žobravých reholí. Biskup mal v tejto oblasti represívnu úlohu akejsi protikacírskej polície. Riadny biskupský súd sa zaoberal zvyčajnými prehreškami proti cirkevnej disciplíne, aj to len vtedy, ak niekto podal žalobu. Okrem toho existoval mimoriadny, inkvizičný súd ( $\mathrm{z}$ lat. inquire = vyhladávat', vyšetrovat', pátrat'). Biskup začínal vyšetrovanie sám od seba, bez podania nejakej žaloby, čiže bol súčasne vyšetrovatelom i sudcom. Na otvorenie procesu stačilo opakujúce sa udanie (clamosa insinuatio) alebo všeobecná fáma (fama publica). Častokrát biskupi konali iniciatívne, prípadne vyzývali na nahlasovanie takých prípadov. Inkvizítor zvyčajne vyhlásil lehotu, počas ktorej mohli všetci bez nebezpečenstva svetského potrestania priznat svoje previnenia. Kajúcnikom boli uložené isté formy pokánia, no podmienkou bolo objasnenie heretických praktík. Nasledovala individuálna fáza procesu. Ak sa obvinený dobrovolne priznal a zriekol sa svojich omylov, nemusel nasledovat fatálny rozsudok. Inkvizítor uložil vinníkovi prísne pokánie, napríklad pút, ale častejšie doživotné väzenie. Ak niekto trval na svojom 
blude, bol odsúdený a odovzdaný svetskému ramenu a upálený „očistným“ ohňom. Biskup tak zo svojho duchovného stáda odstraňoval „choré“ ovce, ktoré by mohli nakazit zdravé. Podla odhadov historikov vo väzení skončilo len asi 10 \% odsúdených a upalovanie bolo skutočnou výnimkou. $\mathrm{Na}$ druhej strane mal biskup osvecovat veriacich dobrým svetlom, ohlasovat dogmy, šírit pravdu (porov. Duby 2002, 135-148; Suchánek - Drška 2013, 288-289). V Uhorsku v ranej románskej dobe existovali ordálie, Božie súdy v biskupských mestách (Stipta 2004, 164-167).

\section{Štyri lateránske koncily}

Stret medzi duchovnou a svetskou mocou, ktorý prebiehal prakticky počas celého 13. storočia, nepohltil všetku energiu cirkvi. Tá zažila búrlivý rozvoj svojich inštitúcií. Každý z lateránskych koncilov sa v nejakej miere zaoberal biskupmi. Najúspešnejším podujatím bol Štvrtý lateránsky koncil za pápeža Inocenta III. Bol zvolaný bulou Vineam Domini Sabaoth („Vinicu Pána zástupov zamýšlajú zničit dravé šelmy..."), zúčastnilo sa ho 1200 biskupov, opátov a delegátov z celej Európy a Blízkeho východu; samotných biskupov bolo prítomných 412. Rokovania prebehli v troch zasadaniach. Koncil reagoval na aktuálne otázky doby: potvrdil teokratickú doktrínu pápežskej moci, odsúdil heretické učenie katarov. Boli prijaté opatrenia na potláčanie heréz, fungovanie inkvizičných súdov, trestanie svetskou mocou. Nešlo o vznik pápežskej inkvizície, ale o posilnenie biskupských tribunálov. Cirkev vytvorila účinný a rýchly nástroj na odstraňovanie odpadlíkov, ale bolo tu vel'ké nebezpečenstvo zneužitia. Koncil priniesol organizačné a disciplinárne zmeny. Odsúdil simoniu a porušovanie celibátu, klerikom zakázal účast’ na slávnostiach, súbojoch, lovoch a vykonávanie chirurgickej praxe. Zakázal život v prepychu a od kňazov žiadal dôstojnost’ pri bohoslužbách. Biskupská stolica nesmela byt' neobsadená viac ako tri mesiace a nedovolovala sa kumulácia benefícií. Tri dekréty sa týkali hierarchie, jeden svetskej organizácie. Metropoliti mali každoročne konat’ provinčnú synodu a dohliadat na volbu biskupov a ich činnost' (Schatz 2014, 100-104; Suchánek Drška 2013, 287-291).

\section{Kánony lateránskych koncilov o biskupoch²}

Na tomto mieste prinášame preklady ustanovení, ktoré sa osobitne dotýkali osoby biskupa alebo jeho služby.

Prvý lateránsky koncil (1123) spomína biskupov v piatich kánonoch:

Kánon 2: Iní biskupi nemajú prijímat' osoby exkomunikované ich vlastnými biskupmi. Zakazujeme, aby tí, ktorí boli exkomunikovaní svojimi vlastnými biskupmi, boli prijímaní do cirkevného spoločenstva inými biskupmi, opátmi či klerikmi.

Kánon 3: Za biskupa možno konsekrovat výlučne osoby vybrané kánonickým spôsobom. Nikto nemôže konsekrovat na biskupa niekoho, kto nebol vybraný kánonickým spôsobom. Ak sa ktosi odváži toto urobit, nech je odstránený z úradu: rovnako konsekrovaná osoba, tak aj konsekrátor, bez žiadnej nádeje na vrátenie pozície.

Kánon 4: Nikto nemôže prebrat' starostlivost’o iné duše bez súhlasu biskupa. Žiadny arcidiakon, arcikňaz, prepošt alebo dekan nech nezverujú nikomu starostlivost’ o duše ani cirkevné prebendy bez rozhodnutia alebo súhlasu biskupa. Rozumie sa, ako to bolo ustanovené v posvätných kánonoch, že starostlivost’ o duše a spravovanie cirkevných záležitostí prináleží

2 Vlastný preklad podla kritického vydania (COD 2013, 187-271). Pre lahšiu orientáciu je každé ustanovenie doplnené nadpisom v kurzíve, ktorý je s prihliadnutím na iné kritické vydanie (DSP 2003). 
úsudku a moci biskupa. Ale ak by sa niekto opovážil privlastnit si oprávnenia prináležiace biskupovi, nech sa zdržiava daleko od brán cirkvi.

Kánon 8: Veriaci laici nemôžu disponovat cirkevným majetkom. Okrem toho v súlade s nariadeniami pápeža Štefana [III.] ustanovujeme, že laici, hoci by boli čo ako vrúcne oddaní cirkevným záležitostiam, nemajú žiadne poverenie na spravovanie cirkevných majetkov, ale v súlade s apoštolskými kánonmi je biskup povinný mat’ správu nad všetkými cirkevnými záležitostami a nech ju tak vykonáva, akoby sa na neho díval Boh. Ak by si niekto z popredných alebo iných laikov privlastnil správu alebo obchodoval s nimi, nech sa na to hladí ako na svätokrádež.

Kánon 18: Farári majú byt' ustanovení biskupmi. Vo farských kostoloch majú byt presbyteri ustanovení biskupmi, ktorí sa pred nimi zodpovedajú za duchovnú správu a za to, čo podlieha biskupovi. Nesmú prijímat desiatky ani chrámy od svetských osôb bez súhlasu a vôle biskupa. Ak sa úmyselne previnia proti právu, budú potrestaní kánonickým trestom.

Druhý lateránsky koncil (1139) spomína biskupov tiež v piatich kánonoch:

Kánon 3: Nech nikto neprijíma osoby exkomunikované ich vlastnými biskupmi. Všemožne zakazujeme, aby ludia exkomunikovaní ich vlastnými biskupmi boli prijímaní inými. Ak sa niekto opováži nesvedomito prijat’ do [cirkevného] spoločenstva exkomunikovanú osobu, pokial nebude oslobodená od trestu, ktorý vyriekol ten, čo ju exkomunikoval, sám upadne do takého trestu.

Kánon 4: Treba pozbavit' cirkevných benefícii tých, ktorí napomínaní svojím biskupom nechcú sa napravit. Nariad’ujeme, aby rovnako biskupi ako i klerici sa usilovali páčit’ sa Bohu i ludom, a to tak duchovne, ako aj navonok. Nech oči tých, pre ktorých majú byt vzorom a príkladom, sa neobhliadajú za prepychom, odevom, farebnostou šiat, ani účesom, ale radšej nech vyžarujú svätost', pretože tá prináleží tomuto stavu. No ak biskupmi napomínaní sa nechcú napravit, budú pozbavení cirkevných benefícií.

Kánon 19: O biskupovi, ktorý sníme z exkomunikovaného trest za podpalačstvo. Ak by nejaký arcibiskup alebo biskup zmiernil trest uložený predchádzajúcim kánonom [18 o podpalačoch], je povinný napravit škody, a okrem toho jeden rok nech sa zdrží od vykonávania biskupského úradu.

Kánon 20: Nech kniežatá vykonávajú spravodlivost po porade s biskupmi. Nech je jasné to, že neodnímame králom a kniežatám moc vo vykonávaní spravodlivosti za účasti arcibiskupov a biskupov ako poradcov.

Kánon 28: Volba biskupov. V prípade smrti biskupa uprázdnenie, podla nariadenia otcov, nesmie trvat dlhšie ako tri mesiace. $V$ tejto súvislosti zakazujeme pod trestom anatémy, aby na biskupskú vol'bu kanonici z biskupského mesta nepripúštali reholníkov, ale opierajúc sa o ich rady nech zvolia za biskupa počestnú a šlachetnú osobu. Ak by sa volba uskutočnila s obídením týchto reholníkov, bude považovaná za neplatnú a daromnú, pretože sa uskutočnila bez ich súhlasu a spoluúčasti.

Tretí lateránsky koncil (1179) spomína biskupov na dvoch miestach:

Kánon 3: Nároky na kandidátov vyberaných do cirkevnej správy. 1. Ked' pri udelovaní svätení a prijímaní cirkevných úradov treba overit, či kandidát dosiahol potrebný vek, zistit povahu jeho zvyklostí, ako aj zrelost', o to viac to treba žiadat' od biskupa, ktorého povinnostou je bdiet nad inými a vlastným príkladom svedčit iným o tom, ako sa treba správat’ v Pánovom dome. 2 . Z toho dôvodu, aby sa vyhlo prípadom nátlaku okolností a času, tiež aby sa ony nestali vzorom pre budúcnost', ustanovujeme týmto nariadením, že nikto nemôže byt’ vybraný za biskupa, ak nedosiahol tridsiaty rok života a nenarodil sa z legitímneho manželského 
zväzku; okrem toho je povinný dat' sa spoznat ako človek hodný uznania vzhladom na svoj život a vychovanie. Po zvolení a potvrdení vol'by, ako aj prijatí správy cirkevných majetkov, po uplynutí kánonmi predpísaného času na biskupskú konsekráciu, pretože mu prináležia benefíciá, nech má výlučné právo disponovat týmito hmotnými dobrami. 3. [Ustanovenie o dekanoch a arcidekanoch.] 4. [Ustanovenie o farároch.] [...] Okrem toho biskup, ak sám nevykoná niečo $\mathrm{v}$ protiklade s týmto právom, alebo to dovolí niekomu inému, stráca právo disponovat vyššie spomínanými benefíciami a táto právomoc prechádza na kapitulu alebo na metropolitu, ak sa kapitula na tom nevie zhodnút.

Kánon 5: Nikoho neslobodno vysvätit bez titulu. Ak by biskup vysvätil niekoho za diakona alebo presbytera bez zabezpečenia titulu, z ktorého by mohol získavat’ prostriedky nevyhnutné pre život, je povinný uspokojovat jeho potreby tak dlho, kým mu neprizná v nejakom kostole náhradu hodnú jeho duchovnej služby; týka sa to situácie, ked’ ten, ktorý prijal svätenie, nemá vlastný majetok alebo dedičný podiel.

Štvrtý lateránsky koncil (1215) spomína vážnost’ biskupskej služby na šiestich miestach:

Kánon 9: Rozličné ríty tej istej viery. 1. Pretože na mnohých miestach v hraniciach jedného miesta a diecézy sa pomiešali ludia hovoriaci rozličnými jazykmi majúci jednu vieru, ale rozličné obrady a zvyky, striktne nariadujeme, aby sa biskupi týchto miest a diecéz postarali o určenie zodpovedných ludí, ktorí by mohli podla rozličných obradov a v rozličných jazykoch slávit pre veriacich bohoslužby, vysluhovat sviatosti, ako aj vyučovat ich ako slovom, tak aj príkladom. 2. Avšak vo všeobecnosti zakazujeme, aby jedno mesto alebo diecéza mala viac biskupov, pretože jedno telo s viacerými hlavami stane sa akýmsi monštrom. Ak by sa $\mathrm{z}$ vyšších príčin vyskytla naliehavá potreba, biskup miesta ustanoví katolíckeho preláta tej istej národnosti, ako majú veriaci, za vikára v spomínaných záležitostiach, ktorý mu bude vo všetkom poslušný a podriadený. 3. Ak by niekto konal inak, nech vie, že ho preniká meč exkomunikácie, a ak nepríde k rozumu, bude odstránený od všetkých cirkevných služieb, súčasne s použitím pomoci svetskej moci s cielom odstránenia tak velkej opovážlivosti.

Kánon 10: Ustanovenie kazatelov. 2. Často sa stáva, že biskupi z rozličných príčin, zlého stavu zdravia, nepriatel'ských nájazdov, či iných dôvodov - nevraviac, že z nedostatku vedomostí, ked'v ich prípade je to vždy vyžadované a v budúcnosti nebude tolerované nech sú sami pripravení poslúžit ludu ohlasovaním Božieho slova, osobitne vo vel'kých a rozsiahlych diecézach. 3. Touto konštitúciou nariadujeme, aby biskupi vyberali sebe zodpovedných mužov, zdatných na plnenie spásonosnej služby svätého poúčania, mocných $\mathrm{v}$ čine i reči, ktorí by ich horlivo zastúpili, ked’ tak nemôžu učinit’ sami, aby im zverených ludí utvrdzovali slovom i príkladom. Biskupi majú povinnost̉ dbat’ o zabezpečenie ich potrieb, aby nedostatok vecí potrebných pre život ich nepriviedol k zanechaniu začatého diela. 4. Preto nariadujeme, aby rovnako v katedrálnych, ako aj kláštorných kostoloch boli vymenovaní zodpovední muži, ktorí by mohli byt pre biskupa pomocníkmi a spolupracovníkmi, nielen v službe ohlasovania, ale rovnako v počúvaní spovedí, udelovaní pokánia, ako aj dalších veciach slúžiacich na spásu duší. Ak niekto toto naplnenie zlahčuje, bude prísne potrestaný.

Kánon 11: Školskí učitelia. 1. Z dôvodu nedostatku prostriedkov sú niektorí zbavení možnosti štúdia a tiež rozvoja. Preto [Tretí] lateránsky koncil vydal zbožné ustanovenie [18], aby „, každom katedrálnom chráme bolo zriadené zodpovedajúce benefícium pre učitela, aby bezplatne vyučoval jeho klerikov a tiež iných chudobných študentov a učiacim sa otváral cestu k poznaniu.“. 2. [...] 3. Metropolitný chrám je rovnako povinný mat’ 
teológa, ktorý by vyučoval kňazov a d’alších Sväté písmo, tiež ich vychovával najmä v tom, čo sa týka pastorácie duší. 4 [...]

Kánon 16: Oblečenie klerikov. 1 - 3 [...] 4. Všetci biskupi, na verejnosti alebo v chráme, nech nosia šaty $\mathrm{z}$ l’anového plátna, iba ak by boli mníchmi, sú povinní nosit mníšsky habit. Nech na verejnosti nenosia vejúce plášte, ale nech ich majú dobre zopnuté pod krkom na hrudi.

Kánon 23: Vakancia v katedrálnom alebo reholnom kostole nemôže trvat dlhšie ako tri mesiace. Aby pre neprítomnost pastiera dravý vlk nenapádal stádo a osirotená cirkev (diecéza) nemala velké škody na svojich majetkoch, túžiac týmto spôsobom zamedzit hroziacim nebezpečenstvám pre duše a zabezpečit nezávislost' cirkví, ustanovujeme, že katedrálny alebo reholný chrám nemôže byt’ bez svojho preláta dlhšie než tri mesiace. Ak v tomto čase tí, ktorým prináleží uskutočnenie volby - len ak by tomu prekážali zákonité dôvody neprevedú volbu, budú pozbavení tohto práva volby. Zase ten, na koho toto právo prejde, majúc pred očami Pána a zohladniac radu svojej kapituly, ako aj iných súdnych mužov, nech nezanedbá, ak chce ujst’ pred kánonickým trestom, kánonické vymenovanie samotnej osoby pre osirelý kostol v lehote troch mesiacov: $\mathrm{z}$ tej alebo onej cirkvi, ak sa v ňom taká nachádzala.

Kánon 58: Interpretácia privilégií v prospech biskupov. Dovolenie udelené niektorým reholníkom rozširujeme na biskupov v prospech biskupského úradu. Dovolujeme, aby v prípade, ked' je nejaké miesto postihnuté všeobecným interdiktom, za zamknutou bránou tichým hlasom a bez zvonenia odbavili bohoslužbu, jedine žeby im to bolo výslovne zakázané. Dovolujeme to len tým [biskupom], ktorí nedali žiadnu príčinu k interdiktu, aby zástupné a protichodné konanie nepremenilo to, čo má priniest̉ úžitok, k nepravej škode.

Prvý lyonský koncil (1245) nemá osobitné ustanovenie týkajúce sa biskupov. Reforma presadená na Druhom lyonskom koncile (1274) zvýraznila úlohu biskupstva, preto niektorí historici považujú tento medzník za koniec románskej doby. V zásade o nej platilo to, čo o pápežskej stolici, do funkcie mali byt vyberaní vzdelaní a morálne spôsobilí muži, bolo kanonizovaných viacero biskupov ako vzorov morálneho života. No vyskytovalo sa dost' biskupov, ktorí viedli luxusný život a pestovali záluby rytierskej, nie duchovnej spoločnosti. Preto sa zvýšil počet pápežských zásahov proti biskupom, ktorí viedli neprimeraný život a neplnili si svoje povinnosti. Nebolo výnimočné, že niektoré biskupské volby neboli potvrdené, ba dokonca boli odmietnuté. Nezohladňovali sa pritom len cirkevné záujmy. Pápežstvo dokázalo častokrát vzdorovat’ svetskému tlaku (Suchánek Drška 2013, 292-293).

\section{Vieroučné (dogmatické) vyjadrenia o episkopáte}

Pri biskupoch sa zdôrazňovala pastoračná služba, najmä ohlasovanie a posväcovanie (Chélini 1996, 233). Bola definovaná biskupská kolegialita a posilnená doktrinálna autorita biskupov. Zdôraznením kolegiality vznikol osobitý spoločenský status biskupov, ktorý bol sakralizovaný náukou o apoštolskej postupnosti, čo znamenalo istú nedotknutelnost'. Samozrejme, pápež to podporil svojím primátom v cirkvi po apoštolovi Petrovi a tým, že je jej viditelnou hlavou. Primát má moc priamo od Krista, nie sprostredkovane od cirkvi. ${ }^{3}$ Posilnenie zodpovednosti za čistotu viery v diecézach na plecia biskupov znamenalo významnú vnútornú autonómiu, ktorú nabúral až

3 Definícia primátu Rímskej stolice je súčastou učenia Magistrátu katolíckej cirkvi (DS 774-775, 811), ktoré bolo definované pápežom Inocentom III. v roku 1199 (Denzinger - Hünermann 2012, 430-433, 462-463). 
rímsky centralizmus po Tridentskom koncile v rámci rekatolizácie. Súčastou posväcovacej úlohy bola plnost' moci, vysluhovanie sviatostí a svätenín.

Napodobnenie sakrálnosti biskupského stavu zrejme inšpirovalo uhorského krála Ladislava, aby v roku 1083 nechal kanonizovat zakladatel'ov vtedy panujúcej král'ovskej dynastie Arpádovcov (zakladatela královstva Štefana a jeho syna Imricha), čím si posilnil autoritu a nedotknutelnost' (Le Goff 2005a, 356). Popritom využil i povest' svätosti benediktínskych mníchov pustovníkov Andreja-Svorada a Benedikta, a biskupa Gerarda. Všetky typy kanonizovaných svätcov boli duchovným pilierom románskej spirituality. Obdobný proces je známy i zo západnej Európy (porov. Potestà 2017).

\section{Záver}

V románskej dobe sa v katolíckej cirkvi zvýraznilo a posilnilo postavenie biskupa, ktorý súčasne získal významné miesto v svetskej spoločnosti (porov. Le Goff 2002, 294-304). Biskupi pôsobili autonómne voči pápežovi, preto sa jednotlivé biskupstvá od seba odlišovali, no isté myšlienkové, kultúrne a duchovné vplyvy globálne ovplyvňovali univerzálne krestanské spoločenstvo. V rámci liturgie bolo biskupské postavenie v hierarchii upevnené rezervovaním istých úkonov, bud’ výlučne pre seba (bolo viazané na biskupskú vysviacku, inak bol úkon neplatný: kňazské ordinácie, birmovanie, konsekrácia kostola a oltára), alebo podliehali jeho licencii, inak bol úkon nedovolený (napríklad požehnanie základného kameňa kostola, nového cintorína, zvonov atd'). Symbolika mala v stredovekej spoločnosti velmi dôležité miesto (porov. Davy 2014; Schmitt 2004; Pastoureau 2018). Biskupi mali významné slovo pri spravovaní krajín, boli poradcami panovníkov a biskupom mohol byt̉ len ten, kto splńal isté kvality (čo bolo novinkou oproti predchádzajúcej dobe), no na druhej strane s vymenovaním nebolo možné obíst' panovníkov. Na toto dedičstvo nadviazal i neskorý stredovek (Kalous 2014, 315-367).

\section{REFERENCES}

Carrol, Warren H. 2009. Historia chrześcijaństwa. Tom III. Złota epoka chrześcijaństwa. Kobierzyce.

COD 2013. Conciliorum oecumenicorum decreta. Edizione bilingue. Alberigo, Giuseppe et alii (eds.). Bologna.

Davy, Marie-Madeleine. 2014. Románská symbolika. Duch 12. století. Praha.

Denzinger, Heinrich - Hünermann, Peter (ed.). 2012. Enchiridion symbolorum, definitionum et declarationum de rebus fidei et morum. $34^{\text {a }}$ edizione bilingue. Bologna.

DSP 2003. Dokumenty soborów powszechnych. Tekst grecki, łaciński, polski. Tom II (869 - 1312). Konstantynopol IV, Lateran I, Lateran II, Lateran III, Lateran IV, Lyon I, Lyon II, Vienne. Baron, Arkadiusz - Pietras, Henryk (eds.). Kraków.

Duby, Georges. 2002. Věk katedrál. Umění a společnost 980 - 1420. Praha.

Dvořáčková-Malá, Dana - Zelenka, Jan et al. 2014. Přemyslovský dvůr. Život knížat, králů a rytířů ve středověku. Praha.

Fried, Johannes - Hehl, Ernst-Dieter (eds.). 2013. Dějiny světa. Globální dějiny od počátků do 21. století 3. Výklady světa a světová náboženství 600 až 1500. Praha.

Hledíková, Zdeňka. 2002. Biskup. In Nodl, Martin - Šmahel, František (eds). Člověk českého středověku. Praha, 139-165.

Chélini, Jean. 1996. Dzieje religijności w Europie zachodniej w śriedniowieczu. Warszawa. 
Jedin, Hubert. 1990. Malé dějiny koncilů. Praha.

Kalous, Antonín. 2014. Biskupské a legátské rituály a ceremonie. In Nodl, Martin - Šmahel, František (eds.). Slavnosti, ceremonie a rituály v pozdním středověku. Praha, 315-367.

Kantorowicz, Ernst H. 2014. Dvě těla krále. Praha.

Kryštůfek, František Xaver. 1889. Všeobecný církevní dějepis. Díl druhý. Stř̌edověk. Část druhá. Květ středověku a klesání jeho ke konci; od papeže Řehoře VII. až do pseudoreformace (1073 1517). Praha.

Lambert, Malcolm. 2000. Středověká hereze. Praha.

Le Goff, Jacques - Schmitt, Jean-Claude. 2002. Encyklopedie středověku. Praha.

Le Goff, Jacques. 1999. Středověký člověk a jeho svět. Praha.

Le Goff, Jacques. 2003. Zrození očistce. Praha.

Le Goff, Jacques. 2005a. Kultura středověké Evropy. Praha.

Le Goff, Jacques. 2005b. Středověká imaginace. Praha.

Leonardi, Claudio (ed.). 2014. Středověká latinská literatura (6. - 15. století). Příručka. Praha.

McGrath, Alister E. 2014. Dějiny křestanství - Úvod. Praha.

Parisse, Michel. 2001. Odrodzenie kleru świeckiego. In Paravicini Bagliani, Agostino et al. Ekspansja Kościoła rzymskiego 1054 - 1274. Warszawa, 209-236.

Pastoureau, Michel. 2011. Medvěd. Dějiny padlého krále. Praha.

Pastoureau, Michel. 2018. Dějiny symbolů v kultuře středověkého západu. Praha.

Patschovsky, Alexander. 2018. Bludiště pravé víry. Sektáři, kacíři a reformátoři ve středověkých Čechách. Praha.

Potestà, Gian Luca. 2017. Poslední mesiáš. Proroctví a panovnická svrchovanost ve středověku. Praha.

Ráček, Blažej. 1940. Církevní dějiny v přehledu a obrazech. Praha.

Roberts, J. M. 2002. Přehledné dějiny světa. Praha; Plzeň.

Roux, Jean-Paul. 2009. Král. Mýty a symboly. Praha.

Schatz, Klaus. 2014. Všeobecné koncily. Ohniska církevních dějin. Brno.

Schmitt, Jean-Claude. 2004. Svět středověkých gest. Praha.

Stipta, István. 2004. Dejiny súdnej moci v Uhorsku do roku 1918. Košice.

Suchánek, Drahomír - Drška, Václav. 2013. Církevní dějiny. Antika a středověk. Praha.

Špirko, Jozef. 1943 [1945]. Cirkevné dejiny s osobitným zretelom na vývin cirkevných dejín Slovenska. Sväzok I. Martin.

Walton, Robert C. - Hannah, John D. - Lynn Peterson, Susan. 2008. Kościoły zachodnie. Chrześcijańskie tablice encyklopedyczne, tom III. Warszawa.

prof. PhDr. ThDr. Peter Zubko, PhD.

University of Ss. Cyril and Methodius

Faculty of Arts

Department of Slovak Language and Literature

Námestie J. Herdu 2

91701 Trnava

Slovakia

peter.zubko@ucm.sk 